\title{
CRISPR 专利之争及对我国科研人员的启示
}

\section{王迁}

华东政法大学知识产权学院, 上海 201620

E-mail:wangqian75@126.com

\section{CRISPR 专利争议的背景和过程}

2017 年初, 一起在美国发生的专利纠纷引起了广泛关 注. 争议的对象是围绕 CRISPR/Cas9 的方法发明. CRISPR 为“Clustered regularly interspaced short palindromic repeats" 的缩写, 是一种改变生物体基因序列的基因编辑过程. 细 菌可以借此将人侵的病毒基因从自己的 DNA 上切除, 从 而实现对病毒的免疫. 其中通过一种蛋白 Cas9 实现的基 因编辑具有巨大的医学应用前景, 有望清除每一个受感染 细胞中的艾滋病或遗传疾病的病毒, 从而治愈许多以往的 绝症. 争议的双方分别是加州大学伯克利分校和由麻省理 工学院和哈佛大学联合设立的 Broad 研究所.

2012 年, 加州大学伯克利分校的生物化学教授 Jennifer Doudna 和 Charpentier 等发表了有关 CRISPR 的论文, 阐明 了如何将 CRISPR/Cas9 基因编辑技术用于在试管中切除目 标位置的 DNA, 随后, 加州大学伯克利分校以此提出了方 法专利申请. 2013 年, Broad 研究所的华人终身教授张锋博 土带领的团队研发出能够在哺乳动物的细胞中编辑基因 序列的 CRISPR/Cas9 系统, 向疾病治疗的目标迈出了至关 重要的一步. Broad 研究所随后也申请了方法专利. 虽然 Broad 研究所提交申请的时间晚于加州大学伯克利分校, 但它利用了“快速审查程序”, 因此首先通过了专利审查并 获得了此项核心专利.

当时的美国《专利法》实行的是“先发明制”, 对于不 同的人独立完成的相同发明创造, 原则上只能授予最先完 成者. 加州大学伯克利分校向美国专利商标局下设的专利 审查和上诉委员会提出申请, 要求认定自己与 Broad 研究 所的发明在本质上是相同的, 只是前者涉及在任何情况下 的基因编辑方法, 而后者仅是将前者应用到哺乳动物的细 胞中而已, 是一种对本领域的技术人员而言显而易见的结 果. 如果该观点成立, 由于两个专利申请针对的是同一发 明, 且由加州大学伯克利分校的研究人员最先完成, 则相 关专利就应当被授权给加州大学伯克利分校, 而不是 Broad 研究所.

专利审查和上诉委员会审理后认为, 与加州大学伯克

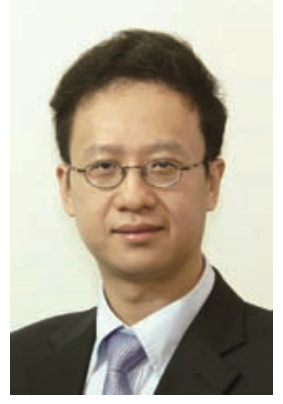

主迁华东政法大学教授、博士生 导师、校学术委员会副主任委员, 享 受国务院政府特殊津贴。入选国家百 千万人才工程, 并被授予“有突出贡 献中青年专家”称号, 入选教育部“长 江学者奖励计划”青年学者项目和“新 世纪优秀人才支持计划”, 被评为“全 国知识产权保护最具影响力人物”、 “全国知识产权领军人才”、“中国版权 卓越成就者”和“上海市优秀中青年法学家”。主持过国家 社会科学基金重大项目等 3 项国家社会科学基金课题和数 项省部级课题.

利分校的技术人员完成的发明，即使用 CRISPR/Cas9 在试 管中编辑基因序列相比，使用 CRISPR/Cas9 在哺乳动物的 细胞中编辑基因序列对本领域的技术人员而言并非显而 易见, 因此属于一项全新的发明. 换言之, 就 Broad 研究 所获得专利的发明而言，张锋博士及其团队成员是“先发 明人”, 该项核心专利授予 Broad 研究所是正确的 ${ }^{1)}$. 当然, 对于专利审查和上诉委员会的决定，当事人可以向美国联 邦巡回上诉法院起诉. 联邦巡回上诉法院有权确认或推翻 该项认定.

\section{CRISPR 专利争议涉及的法律问题}

此次专利争议的双方均为科研机构, 本身并不直接从 事商业活动, 为什么双方对 CRISPR 核心专利都如此看重? 这是因为专利可以通过许可带来可观的经济利益. 一旦就 一种新方法获得了专利权, 专利权人就可以对该方法享有 排他性的使用权. 但这种“使用权”并不意味着专利权人自 己一定可以使用, 因为许多方法的实际使用还需要根据其 他法律获得特别许可. 例如要将 CRISPR 核心专利应用于 疾病治疗, 在患者体内的细胞中编辑基因序列, 就需要得 到医疗监管部门(如美国的 FDA)的批准，获得专利权并不 是实施这种医疗行为的通行证. 方法专利的意义在于：他

1) 参见美国专利商标局专利审查和上诉委员会 2017 年 2 月 15 日裁决书 
人如果要使用该方法, 除了《专利法》规定的例外, 必须 获得专利权人的许可. 由于 CRISPR 核心专利具有广泛的 商业应用前景, 未来生物技术公司和制药企业如果要使用 相同的方法开展基因治疗, 就需要取得许可, 这就可以为 专利权人带来可观的许可收人.

本次 CRISPR 专利争议也与修改之前的美国《专利法》 实行“先发明制”有关. 如前所述, 在“先发明制”中, 独立 完成了相同发明的人如果先后提出专利申请, 原则上只能 由先完成者, 而不是由先申请者获得专利权. 因此加州大 学伯克利分校一方面认为张锋团队的发明与本校研究人 员的发明相同, 一方面主张本校研究人员完成发明在先.

但是, 美国《专利法》已经被修改, 自 2013 年 3 月 16 日起, “先申请制”取代了原先的“先发明制”. 根据修改 后的美国《专利法》, 如果两人各自独立完成了相同的发 明并申请专利权, 专利原则上应授权给完成发明较晚但申 请日在先的发明人, 而不是完成发明较早但申请日在后的 发明人. 当然, 为了确保公平, 修改后的美国《专利法》还 有一些特殊的规定 (35 USC 102(a)). 如两人各自独立完成 了相同的发明之后, 都以发表论文等方式公开了各自的发 明, 然后都在公开后一年之内申请专利权, 此时先公开者 才可能被授予专利权. 据此, 在美国完成发明之后, 先发 表论文, 然后在一年之内申请专利, 仍然是一种可行的方 法(35 USC 102(b)(1)).

与“先申请制”密切相关的概念就是“新颖性”. “新颖 性” 是获得专利的前提条件之一, 意为相关发明必须是 “新”的, 而不是“旧”的. “新”与“旧”的判断, 除了上文提及 的“公开后一年内申请”等例外情况, 就以提出专利申请之 日一一申请日”为准. 如果在申请日之前, 发明的内容已 经为公众知, 就无法获得授权. 例如, 发明人以论文形式 将发明公开之后两年才申请专利, 由于在申请日之前, 该 发明已为公众所知, 而且发明人的公开时间距申请日已超 过一年, 根据美国《专利法》的规定, 该申请因缺乏新颖 性而无法被批准. 再如, 中国和美国的科研人员各自独立 完成了相同的发明, 中国科研人员先发表了论文, 美国科 研人员后申请专利, 由于在美国科研人员提出申请之前, 公众已经可以通过中国科研人员的论文了解此项发明的 内容, 美国科研人员的申请不符合新颖性的要求, 应被美 国专利商标局驳回.

获得专利的另一个条件是“非显而易见性”(在中国等 国的《专利法》中称为“创造性”). 如果说“新颖性”要求“新”, “非显而易见性”则要求 “难”一一如果某项成果对于本领域 的技术人员而言是显而易见的, 无需创造性劳动就可获得, 即使它与之前的成果相比有些差异, 也并不能获得专利权. 在本案中, 争议焦点就在于: 对于本领域的技术人员而言, 根据加州大学伯克利分校的研究人员在先完成的有关 CRISPR 的方法发明, 张锋团队的成果本质上与之是否是
一回事, 是否是显而易见的? 这当然是一个高度技术性的 问题, 需要根据相关证据作出认定. 专利审查和上诉委员 会认为张锋团队的成果并非显而易见, 因为在体外编辑 基因序列与在哺乳动物的细胞中编辑基因序列存在极大 差异.

\section{CRISPR 专利争议对我国科研人员的启示}

CRISPR 专利之争尽管发生在美国, 但也能给我国科 研人员带来一定的启示. 首先, 科研人员或科研机构应当 积极申请专利, 以维护自己的合法权益, 防止他人对研究 成果无偿进行商业利用. 在过去很长一段时间内, 我国科 研人员和科研机构受到“君子喻于义, 小人喻于利”的传统 思想以及科研考核机制影响，对于符合专利授权条件的科 研成果, 往往只重视科研论文而不考虑申请专利, 同时对 于何种科研成果符合获得专利的条件，以及如何申请专利 也缺乏必要的了解. 但是, 当今世界, 对科研成果的商业 化开发利用日益重要, 而专利不仅是保护发明创造的重要 手段, 也是展开市场竞争的利器. 获得了专利权, 在激烈 的国际竞争中就有了话语权. 因为他人需要对已获专利的 成果进行商业利用时, 就必须寻求专利权人的许可. 如果 我方也需要使用对方已获专利的成果时, 就可以利用已方 的专利与对方进行交叉许可, 从而掌握主动权. 加州大学 伯克利分校和 Broad 研究所作为纯研究机构, 为 CRISPR 专利展开法律争夺, 充分说明了这一点.

其次, 对专利的申请还应当及时提出. 在本次 CRISPR 核心专利争议中, 双方研究人员均是先发表论文, 再申请专 利, 这与当时美国《专利法》规定的“先发明制”有关. 在美 国《专利法》修改之后, 发明人如果先发表论文, 再在一年 内申请专利, 其申请仍然具备新颖性, 有可能获得授权. 但 我国和许多其他国家不但实行“先申请制”，而且采取了严 格的新颖性标准, 与美国《专利法》的规定不同. 在我国, 发 明人在申请专利之前, 如果通过发表论文等方式公开其发 明, 除了法定例外, 此后的专利申请将不具备新颖性, 发明 人将无法获得授权. 法定例外是指: 在以下三种情形下, 6 个月内申请专利权的, 不丧失新颖性: (一) 在中国政府主办 或者承认的国际展览会上首次展出的; (二) 在国务院有关 主管部门或者全国性学术团体组织召开的学术会议或者技 术会议上首次发表的; (三) 他人未经申请人同意而泄露其 内容的. 根据该项规定 ${ }^{[2]}$, 如果在发生上述三种情形 6 个月 之后再申请专利权的, 仍然无法获得授权(《专利法》第 24 条). 同时, 假如在此期间他人独立完成了相同的发明创造 并申请专利, 由于其申请日在先, 首先完成发明并参展或发 表的人将无法获得专利权. 当然, 由于他人在申请专利之前, 相关成果的内容已经通过上述三种情形之一公开, 已不具 备新颖性, 他人也无法获得专利权. 如果此次 CRISPR 核心 专利争议发生在中国, 由于双方在申请日之前均已发表了 
论文, 只要论文充分公开了发明内容, 而且这种公开不属于 我国《专利法》规定的三种例外情形之一, 双方的专利申请 都会因不具备新颖性而被驳回.

由此可见, 完成科研成果之后, 只要符合专利授权条 件, 应当立即申请专利, 而不是首先发表论文之后再申请. 科研人员应当学习《专利法》和有关专利申请的基本知识, 了解哪些科研成果符合专利授权条件以及提出专利申请 的方法和途径, 给予专利申请和发表科研论文同等程度的 重视. 避免将耗费大量心血完成的, 且本可以获得专利的 发明创造被他人无偿地进行商业性使用. 在提出专利申请 之后发表论文, 就不会对专利申请造成负面影响. 因为“新 颖性” 是以申请日为基准的, 申请日之后对科研成果的公 开, 不会使在先的申请丧失新颖性.

最后, 科研机构要重视申请专利的权利. 在 CRISPR 专利争议中, 双方的专利申请人均是科研机构, 而不是研 究人员个人. 实际上, 美国《专利法》将专利申请权赋子 了发明人, 而不是发明人所在的机构. 但在实务中, 由于 发明往往需要机构投人大量资金和人员支持才能完成, 研 究人员通常会与机构签订合同, 将申请专利的权利转让给
机构. 因此加州大学伯克利分校和 Broad 研究所才分别申 请了专利. 美国科研机构对专利申请的重视度可见一斑.

我国《专利法》则区分情况对申请专利的权利作出了 规定. 对于职务发明, 也就是执行本单位的任务或者主要 是利用本单位的物质技术条件所完成的发明，申请专利的 权利属于该单位。申请被批准后，该单位为专利权人，但 单位应当给予发明人以奖励. 对于非职务发明, 申请专利 的权利则属于发明人. 申请被批准后, 该发明人为专利权 人《专利法》第 6 条. 因此, 科研人员如果是执行所属科 研机构的任务或主要利用了该科研机构的物质技术条件 完成了一项发明, 该科研机构享有申请专利的权利, 科研 人员不能以个人的名义提出专利申请. 由科研机构申请专 利, 便于在获得专利权后进行专利管理和许可, 以充分发 挥专利的价值. 因此, 我国科研机构应当充分利用《专利 法》赋予的权利, 重视对专利的申请.

总之, 尽管中美两国的《专利法》在一些具体规定上 有所不同, 但基本原理是相通的. 通过此次 CRISPR 专利 争议, 我国科研人员和科研机构可以提高专利意识, 学会 运用法律手段积极争取和维护自身的权益.

\section{推花阅读文献}

1 Durham A L. Patent Law Essentials. Westport: Praeger Publishers, 2009

2 State Intellectual Property Office of the People's Republic of China. Guidelines for Patent Examination (in Chinese). Beijing: Intellectual Property Publishing House, 2010 [国家知识产权局. 专利审查指南. 北京: 知识产权出版社, 2010]

3 Jin H J. The nature of the first-inventor-to-file rule: A comparative study based on section 102 of the U.S. Patent Act (in Chinese). J Intellect Property, 2013, 4: 73-85 [金海军. 从美国《专利法》第 102 条第看发明人先申请制的实质. 知识产权, 2013, 4: 73-85] 


\title{
The dispute on the CRISPR patent and the lessons for Chinese researchers
}

\author{
WANG Qian \\ School of Intellectual Property, East China University of Political Science and Law, Shanghai 201620, China \\ E-mail: wangqian75@126.com
}

The method inventions surrounding CRISPR have the potential to effectively kill virus and cure diseases, and the dispute on the ownership of the relevant patent between UC Berkley and Broad Institute reflects the importance of patent for the following commercialization of the invention. The keys to solve the dispute are whether the two applications for patent submitted respectively by UC Berkley and Broad Institute involve essentially the same invention and who made the invention first. The Patent Trial and Appeal Board in the USPTO decided that the two inventions are substantially different, so Broad Institute won the case. Chinese researcher may learn a lot from this legal battle. Firstly, researchers should actively apply for patent to protect their legitimate rights and to prevent others from commercializing the research fruits free of charge, and their awareness of patent law, including whether their research results meet the requirements of patent, how and when to make the application, need to be promoted. Secondly, the application for patent should be submitted on time. The Patent Law of China is dramatically different from the US Patent Act in that the inventor cannot obtain patent in China if he or she disclosed the invention to the public before the date of application, and this rule is only subject to very limited exceptions, while under the US Patent Act, an inventor enjoys one year of grace to apply for patent after he or she disclosed the invention. Thirdly, research institutes need to attach importance to patent application. The China Patent Law provides that the right to apply for patent on "invention made for hire" belongs to the institute where the inventor is employed. Therefore, a researcher as the inventor cannot make a personal application if the invention is made for the purpose of finishing the tasks of the institute to which the researcher belongs, or made by the researcher mainly by using the materials and technical means of the institute. That rule contrasts the US Patent Act, which gives the inventor the right to apply for patent even in the case of "invention made for hire". But most US research institutes obtain the right to apply for patent by contract with their researchers who agree to transfer the right to the institutes. It is suggested that Chinese research institutes put more emphasis on patent application.

\section{CRISPR patent, patent application, invention made for hire}

doi: 10.1360/N972017-00333 